\title{
In-situ analysis of redistribution of carbon and nitrogen during tempering of low interstitial martensitic stainless steel
}

\author{
Niessen, F.; Villa, M.; Danoix, F.; Hald, J.; Somers, M. A.J.
}

\section{Published in:}

Scripta Materialia

Link to article, DOI:

10.1016/j.scriptamat.2018.06.004

Publication date:

2018

Document Version

Peer reviewed version

Link back to DTU Orbit

Citation (APA):

Niessen, F., Villa, M., Danoix, F., Hald, J., \& Somers, M. A. J. (2018). In-situ analysis of redistribution of carbon and nitrogen during tempering of low interstitial martensitic stainless steel. Scripta Materialia, 154, 216-219. https://doi.org/10.1016/j.scriptamat.2018.06.004

\section{General rights}

Copyright and moral rights for the publications made accessible in the public portal are retained by the authors and/or other copyright owners and it is a condition of accessing publications that users recognise and abide by the legal requirements associated with these rights.

- Users may download and print one copy of any publication from the public portal for the purpose of private study or research.

- You may not further distribute the material or use it for any profit-making activity or commercial gain

- You may freely distribute the URL identifying the publication in the public portal 


\section{In-situ analysis of redistribution of carbon and nitrogen during tempering of low interstitial martensitic stainless steel}

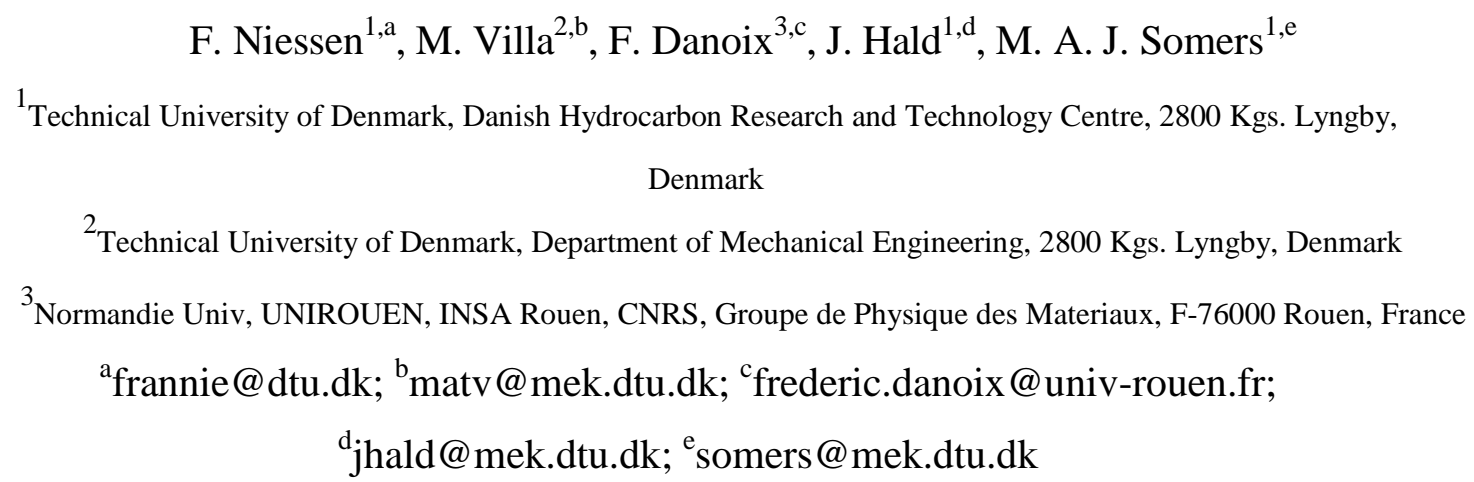

Abstract. The redistribution of $\mathrm{C}$ and $\mathrm{N}$ during tempering of X4CrNiMo16-5-1 martensitic stainless steel containing 0.034 wt.\% C and 0.032 wt.\% $\mathrm{N}$ was studied using in-situ synchrotron X-ray diffraction (XRD) and atom probe tomography (APT). The unit cell volume of martensite decreased continuously during tempering. APT showed that this volume decrease is accounted entirely for by segregation of the interstitial atoms, implying that in low interstitial martensitic stainless steel stress relaxation only contributes negligibly to changes in the martensite unit cell volume.

Keywords: tempering, segregation, martensitic steels, synchrotron radiation, atom probe tomography

Martensitic steels with lath microstructure stand out by an exceptional combination of high strength, good ductility and low cost for numerous structural applications. These properties are conventionally obtained through a hardening and tempering heat treatment cycle. Hardening consists of high temperature austenitization followed by martensite formation during fast cooling to room temperature. With a dislocation density comparable to that of heavily cold rolled ferrite, martensite is brittle and thus unsuitable for practical use [1]. Tempering of the hardened material below $\mathrm{A}_{\mathrm{c} 1}$ promotes optimization of the mechanical properties through redistribution of the interstitial atoms and relaxation of internal stresses [2]. In martensitic stainless steels, annealing in the inter-critical region between $A_{1}$ and $A_{3}$ leads to formation and stabilization of reversed austenite at lath boundaries [3-5]. Such dual phase microstructure significantly enhances toughness and ductility, and reduces yield strength, hardness and ultimate tensile strength [6-8]. 
1 A few in-situ studies focused on tempering of martensitic stainless steels with more than

20.6 wt.\% interstitial content below $\mathrm{Ac}_{1}[9,10]$, or on inter-critical annealing of

3 martensitic stainless steels with less than $0.08 \mathrm{wt} . \%$ interstitial content [4,11-13]. These

4 in-situ studies were based on measurement of the planar spacings of the present phases

5 as a function of temperature with synchrotron X-ray diffraction (XRD). Tempering

6 below $\mathrm{Ac}_{1}$ in low interstitial martensitic stainless steels appears still uninvestigated.

7 Generally, it is not possible to distinguish unequivocally between the contributions of

8 changes in interstitial content in solid solution and changes in internal stresses on the

9 evolution of the austenite and martensite unit cell volumes. In martensite, the change in

10 tetragonality of the unit cell with $\mathrm{C}$ and $\mathrm{N}$ content [14] is a widely applied relation to

11 determine the interstitial content $[9,15,16]$. In the present system, the martensite unit

12 cell must be regarded as cubic, because of the low total interstitial $(\mathrm{C}+\mathrm{N})$ content [14].

13 Hence, the unit cell volume is represented by a single lattice parameter. For cubic

14 martensite, as well as for austenite, XRD studies which involve both changes in

15 chemistry and stresses are either limited to semi-quantitative conclusions based on 16 assumptions [10,15,17-20], or rely on additional results from numerical modeling $17[9,21,22]$. The present study aims to elucidate the interpretation of changes in the unit 18 cell volume of martensite during tempering by correlating in-situ energy-dispersive 19 synchrotron X-Ray diffraction (XRD) with atom probe tomography (APT) results.

20 The steel investigated has the metallic composition Fe-15wt.\%Cr-5.8wt.\%Ni21 1.0wt.\%Mo-0.86wt.\%Mn-0.4wt.\%Si (EN 1.4418) measured by optical emission 22 spectroscopy as well as $0.034 \pm 0.0048$ wt.\% $\mathrm{C}$ and $0.032 \pm 0.0006 \mathrm{~N}$ wt.\% as 23 interstitials, measured by LECO CS230 and LECO TC500 instruments, respectively. 24 Samples from an extruded rod of $\varnothing 10 \mathrm{~mm}$ were austenitized at $1223 \mathrm{~K}$ for $6 \mathrm{ks}$ in an $\mathrm{Ar}$ 25 flow, where the average heating and cooling rate were 0.75 and $1.15 \mathrm{~K}^{-1}{ }^{-1}$, respectively. 26 The martensite start temperature $\left(\mathrm{M}_{\mathrm{S}}\right)$ of the material is $408 \mathrm{~K}$, and the amount of 27 retained austenite at room temperature is $3.5 \pm 0.5$ vol.\% [23]. Microstructure 28 characterization revealed that retained austenite is present as bulky retained austenite, 29 mostly in the corners of martensite packets.

30 In-situ XRD was carried out on the EDDI-beamline of the synchrotron facility HZB31 BESSY II [24] and consisted of high temperature measurement of the evolution of the 
1 unit cell volumes of the phases. Sample preparation, experimental setup and measuring

2 conditions are described in Ref. [23].

3 Residual stresses can be categorized according to the length scale over which they 4 equilibrate. Macro-stresses (type I) occur over large distances within a sample, micro5 stresses of type II equilibrate at the grain or phase scale, and micro-stresses of type III 6 are stresses which occur at a level considerably smaller than the grain size [25,26]. 7 Stresses are manifested as lattice strains and, for polycrystalline mono-phase materials 8 with random grain orientation, lead to line profile shifts (type I) or line profile 9 broadening (type II and III) in XRD. For dual-phase polycrystalline materials, as under consideration in the present work, stresses of type I are partitioned into phase specific stresses of type II, which lead to phase specific line profile shifts, while broadening of the line profiles reflects the variation in phase specific stresses of type II and stresses of 13 type III.

The austenite-to-martensite transformation in steel is associated with a shape change, a so-called transformation strain, which, in average, invokes a state of phase-specific hydrostatic residual stress of type II in the material with contributions from the transformation itself and thermal mismatch [23]. In a thin sample, as under consideration in the present study, macro-stresses (type I) are considered biaxial, i.e. relaxed in the direction normal to the sample surface, and can be separated from hydrostatic type II stresses by measuring over several $\psi$ angles [26,27]. Stresses were determined from the arithmetic average of the lattice parameters from the $211_{\alpha^{\prime}}, 220_{\alpha}$, and $321_{\alpha}$, reflections, weighted by their multiplicity. Further details on the applied methodology and the X-ray elastic constants are given in Ref. [23].

24 The lattice parameter of martensite was acquired during the thermal cycles depicted in

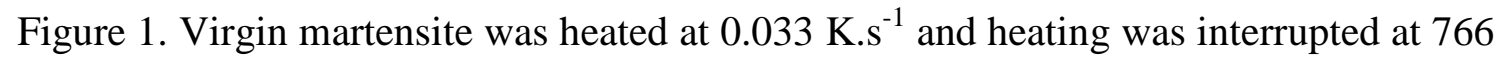
K to prevent nucleation of austenite (Figure 1(a)). A second heating cycle was applied to obtain the reference lattice parameter of tempered martensite (Figure 1(b)). For the accurate determination of lattice strains with the $\sin ^{2} \psi$ method stationary conditions are required. For this reason, the average heating rate of $0.033 \mathrm{~K} . \mathrm{s}^{-1}$ was realized by rapid heating by $18 \mathrm{~K}$ at $0.6 \mathrm{~K} . \mathrm{s}^{-1}$, $80 \mathrm{~s}$ of temperature equilibration and $430 \mathrm{~s}$ measurement for a range of $\psi$ angles (see inset in Figure 1, intervals (i), (ii) and (iii), respectively). It was found for martensite that phase specific macro stresses, i.e. biaxial stresses 
1 determined by the $\sin ^{2} \psi$ method, were in the range of -30 to $30 \mathrm{MPa}$ for the entire

2 thermal cycle and thus can be neglected.

3 The change in the lattice parameter of martensite during tempering of virgin martensite $4 \quad\left(a_{\text {temp }}\right.$, cycle $(a)$ in Figure 1$)$ relative to the lattice parameter of tempered martensite 5 ( $a_{\text {ref }}$, cycle $(b)$ in Figure 1$)$ is represented by the green dots in Figure 2. The green 6 dashed line represents data from the experimental points, smoothed with the Savitzky7 Golay method and a 5 point window. Since no biaxial stresses are present, this relative 8 change in lattice parameter can be conceived as the average value of the phase specific 9 hydrostatic lattice strains of type II [26]. Evidently, on tempering the volume of the 10 martensite unit cell is reduced relative to the reference condition. The volume fraction 11 of retained austenite was too small to allow accurate lattice strain determination

12 The change in lattice parameter of martensite may be an effect of partitioning of 13 mechanical stress, but may also be the result of a redistribution of interstitials. 14 Interpreting the contraction in terms of a change in total interstitial content, the wellestablished relationships for Fe-C and Fe-N martensite from Ref. [14] could be applied. 16 Recognizing that both $\mathrm{N}$ and $\mathrm{C}$ are present, the arithmetic average of the dependence of 17 unit cell volume on interstitial ( $\mathrm{N}$ or $\mathrm{C}$ ) content can be used to estimate the change in 18 total interstitial content ${ }^{1}$ :

$$
V_{M e}=1.177610^{-2}+8.210^{-5} y_{N+C}\left[\mathrm{~nm}^{3}\right]
$$

19 where $V_{M e}$ is the volume per metal atom and $y_{N+C}$ is the total number of interstitials per 20100 metal atoms. This conversion of relative contraction of the unit cell volume into the 21 change of total interstitial content from the initially average alloy interstitial content is 22 given on the right-hand vertical axis in Figure 2.

23 Assuming a pure effect of rejection of $\mathrm{C}$ and $\mathrm{N}$ on the relative change in the martensite 24 lattice parameter, the measured change in lattice parameter corresponds to a progressive

\footnotetext{
${ }^{1}$ Adopting the average of the lattice expansions caused by $\mathrm{C}$ and $\mathrm{N}$ an error of maximally $1 \%$ is introduced, which is within experimental accuracy.
} 
1 rejection of $\mathrm{C}$ and $\mathrm{N}$ from solid solution in martensite (green dashed line in Figure 2).

2 Altogether $y_{c+N}=0.18$ is rejected, while $y_{c+N}=0.10$ remains in solid solution.

3 In order to verify the validity of the hypothesis of a mere rejection of interstitials, local 4 composition measurements with atom probe tomography (APT) were conducted for 5 specimens in the hardened condition and specimens tempered by heating to $568 \mathrm{~K}$ and $6703 \mathrm{~K}$ at the same heating rate as in the XRD investigations. Needle-shaped specimens 7 for APT were prepared by electrolytic polishing [28] and subsequently field-evaporated 8 in a CAMECA LEAP $4000 \mathrm{HR}{ }^{\circledR}$ in voltage mode. The analysis was conducted at $50 \mathrm{~K}$, $920 \%$ pulse fraction, $200 \mathrm{kHz}$ pulse rate and $0.3 \%$ detection rate in legacy mode. In mass spectra, carbon was detected as $\mathrm{C}^{+}, \mathrm{C}^{2+},\left({ }^{2} \mathrm{C}\right)^{2+},\left({ }^{3} \mathrm{C}\right)^{2+}$ and $\mathrm{C}^{3+}$ ions and compositions were determined following the peak assignment proposed by Sha et al. [29]. Singly charged nitrogen overlaps with doubly charged Si, but as no characteristic shoulder for the $\mathrm{Si}^{2+}$ was observed, and nitrogen has a strong tendency to form molecular ions with Mo [30], virtually all $\mathrm{N}$ was detected as $(\mathrm{MoN})^{2+}$. Grain boundaries were identified by qualitative structural analysis of the desorption pattern, [31]. The method consisted of analyzing the shift of crystallographic poles across grain boundaries, which is a measurement of grain boundary misorientation. In the tempered conditions, identification of grain boundaries was confirmed by the local increase in the $\mathrm{C}$ and $\mathrm{N}$ contents. The standard deviation of interstitial content $y$ in terms of counting statistics [32] of individual measurements was $<2.5 \times 10^{-3}$ for both $\mathrm{C}$ and $\mathrm{N}$.

A representative example of an APT analysis is given in Figure 3 for the sample heated to $703 \mathrm{~K}$. Two low-angle grain boundaries (LAGBs), i.e. lath boundaries, are associated with a local increase in the $\mathrm{C}$ and $\mathrm{N}$ contents. The average bulk contents were determined in the marked region, where the $\mathrm{C}$ and $\mathrm{N}$ contents are approximately constant and unaffected by segregation at the LAGBs and/or depletion in the adjacent region. The region boundaries were positioned in safe proximity (several $\mathrm{nm}$ ) away from segregation features. For mainly two reasons no mathematical criterion was applied to define the region boundaries. Firstly, the distribution of $\mathrm{C}$ and $\mathrm{N}$ at a segregation feature depends on the specific configuration and neighborhood of individual grain boundaries so that they cannot be accessed by a global composition criterion. Secondly, a composition gradient criterion would be too sensitive to the noisy $\mathrm{C}$ and $\mathrm{N}$ content profiles along the specimen axis in the case of low interstitial martensitic stainless steel. 
1 APT revealed no segregation at lath boundaries in the hardened condition and a uniform 2 distribution of interstitials within each analyzed specimen. The absence of interstitial 3 segregation at lath boundaries and low deviation in interstitial content from different 4 specimens of the hardened condition (see error bars in Figure 2) suggests that martensite 5 formation from $408 \mathrm{~K}$ and below occurs without auto-tempering, and that no noticeable 6 aging occurred during storage of the sample at room temperature over 6 months. 7 Clustering of $\mathrm{C}$ and $\mathrm{N}$ was observed in the $703 \mathrm{~K}$ condition, but no transition- or alloy8 carbides were found, which is in agreement with investigations on a maraging stainless 9 steel with 0.05 wt.\% C [33].

The average bulk contents of $\mathrm{N}$ and $\mathrm{C}$ determined by APT for the three conditions are included in Figure 2. The determined $\mathrm{C}$ and $\mathrm{N}$ contents of $0.036 \pm 0.0030$ wt.\% and $0.032 \pm 0.0015$ wt.\% in the hardened condition are in excellent agreement with the bulk contents of $0.034 \pm 0.0048$ wt.\% and $0.032 \pm 0.0006$ wt.\%, respectively. Comparison of the evolution of the total interstitial content determined by APT with the change in lattice parameter (Figure 2) shows excellent agreement. As a consequence, it can be concluded that the evolution of the martensite lattice parameter can be explained solely by a change in total interstitial content in solid solution.

Previously it was found for the same alloy that martensite experiences an average 40 MPa hydrostatic tensile stress and that the minority phase austenite experiences an average of 890 MPa hydrostatic compressive stress in the hardened condition [23], while the total macro stress is close to nil. It could therefore be argued, that the change in martensite lattice parameter during tempering is an effect of relaxation of the hydrostatic component of the stress state rather than a change of the interstitial content in martensite. Interpretation of the change in martensite lattice parameter before and after tempering in terms of average hydrostatic stress corresponds to $-320 \mathrm{MPa}$, which is too large to account for stress relaxation of $40 \mathrm{MPa}$. Furthermore, relaxation of the tensile state of stress in martensite compared to a compressive state of stress in austenite would induce partitioning of interstitials in the reverse direction, i.e. martensite can release the tensile hydrostatic component of the stress state by absorbing more interstitials, while austenite can release the hydrostatic component of the compressive stress by depletion of interstitials. APT shows that the reverse is happening, implying 
1 that a reduction of the strain energy is not the dominant driving force for partitioning of 2 the interstitials.

3 Summarizing, the present work shows that $\mathrm{C}$ and $\mathrm{N}$ are initially homogeneously 4 distributed in the hardened condition in low interstitial martensitic stainless steel and that 5 tempering leads to progressive rejection of $\mathrm{C}$ and $\mathrm{N}$ from solid solution and segregation 6 to mainly grain boundaries. Interpretation of the change in unit cell volume of martensite 7 during tempering as a change in interstitial content in martensite shows excellent 8 agreement with a change of the bulk interstitial content as determined by APT. Thus, for 9 the present system, the change in unit cell volume of martensite during tempering can be 10 directly interpreted as a change in total interstitial atom content in the martensitic matrix.

11 M. Klaus, D. Apel and Ch. Genzel from Helmholtz Zentrum für Materialien und Energie 12 (HZME) are acknowledged for their support during the activity at the HZB-BESSY II 13 synchrotron facility. The activity was supported by the European Commission under the 14 7th Framework Program through the 'Research Infrastructure' action of the 'Capacities' 15 Programme, CALIPSO (Grant n: 312284). The Danish Underground Consortium is 16 gratefully acknowledged for financial support to the Danish Hydrocarbon Research 17 Center (DHRTC). 


\section{References}

[1] M. Natori, Y. Futamura, T. Tsuchiyama, S. Takaki, Scr. Mater. 53 (2005) 603608.

[2] G.R. Speich, Trans. Metall. Soc. AIME 245 (1969) 2553-2564.

[3] F. Niessen, F.B. Grumsen, J. Hald, M.A.J. Somers, in:, Proc. 24th IFHTSE Congr., 2017, pp. 138-145.

[4] F. Niessen, M. Villa, D. Apel, O. Keßler, M. Reich, J. Hald, M.A.J. Somers, Mater. Sci. Forum 879 (2017) 1381-1386.

[5] F. Niessen, Mater. Sci. Technol. 836 (2018) 1-14.

[6] P. Brezina, B. Sonderegger, Härterei-Technische Mitteilungen 33 (1978) 1-12.

[7] M. Al Dawood, I.S. El Mahallawi, M.E. Abd El Azim, M.R. El Koussy, Mater. Sci. Technol. 20 (2004) 370-374.

[8] M. Grounes, S. Rao, Trans. ASM 62 (1969) 902-914.

[9] A. Bénéteau, E. Aeby-Gautier, G. Geandier, P. Weisbecker, A. Redjaimia, B. Appolaire, Acta Mater. 81 (2014) 30-40.

[10] G. Geandier, E. Aeby-Gautier, A. Settefrati, M. Dehmas, B. Appolaire, Comptes Rendus Phys. 13 (2012) 257-267.

[11] J.D. Escobar, G. Faria, L. Wu, J.P. Oliveira, P.R. Mei, A.J. Ramirez, Acta Mater. 138 (2017) 92-99.

[12] M. Wiessner, E. Gamsjäger, S. van der Zwaag, P. Angerer, Mater. Sci. Eng. A 682 (2017) 117-125.

[13] F. Niessen, M. Villa, J. Hald, M.A.J. Somers, Mater. Des. 116 (2017) 8-15.

[14] L. Cheng, A. Böttger, T.H. de Keijser, E.J. Mittemeijer, Scr. Metall. Mater. 24 (1990) 509-514.

[15] J. Epp, T. Hirsch, C. Curfs, Metall. Mater. Trans. A 43 (2012) 2210-2217.

[16] B. Kim, J. Sietsma, M.J. Santofimia, Philos. Mag. 96 (2016) 2632-2648.

[17] B. Kim, J. Sietsma, M.J. Santofimia, Mater. Des. 127 (2017) 336-345.

[18] J. Epp, Adv. Mater. Res. 996 (2014) 525-531.

[19] S. Allain, G. Geandier, J.-C. Hell, M. Soler, F. Danoix, M. Gouné, Metals. 7 (2017) 232.

[20] T.D. Bigg, D. V. Edmonds, E.S. Eardley, J. Alloys Compd. 577 (2013) S695S698.

[21] S.Y.P. Allain, G. Geandier, J.C. Hell, M. Soler, F. Danoix, M. Gouné, Scr. Mater. 131 (2017) 15-18.

[22] S.Y.P. Allain, S. Gaudez, G. Geandier, J.-C. Hell, M. Gouné, F. Danoix, M. Soler, S. Aoued, A. Poulon-Quintin, Mater. Sci. Eng. A 710 (2017) 245-250.

[23] M. Villa, F. Niessen, M.A.J. Somers, Metall. Mater. Trans. A 49 (2018) 28-40.

[24] C. Genzel, I. Denks, M. Klaus, Mater. Sci. Forum 524-525 (2006) 193-198.

[25] P.J. Withers, H.K.D.H. Bhadeshia, Mater. Sci. Technol. 17 (2001) 355-365.

[26] V. Hauk, in:, Struct. Residual Stress Anal. by Nondestruct. Methods, Elsevier, 1997, pp. 132-215.

[27] E. Macherauch, P. Müller, Zeitschrift Für Angew. Phys. 13 (1961) 305-312.

[28] M.K. Miller, G.D.W. Smith, Atom Probe Microanalysis: Principles and Applications to Materials Problems, Materials Research Society, USA, 1989.

[29] W. Sha, L. Chang, G.D.W. Smith, L. Cheng, E.J. Mittemeijer, Surf. Sci. 266 (1992) 416-423.

[30] M.K. Miller, R. Forbes, Atom Probe Tomography: The Local Electrode Atom Probe, Springer US, 2014.

[31] B. Gault, M.P. Moody, J.M. Cairney, S.P. Ringer, Mater. Today 15 (2012) 378386. 
1 [32] F. Danoix, G. Grancher, A. Bostel, D. Blavette, Ultramicroscopy 107 (2007)

2 739-743.

3 [33] C. Servant, E.H. Gherbi, G. Cizeron, J. Mater. Sci. 22 (1987) 2297-2304. 
1

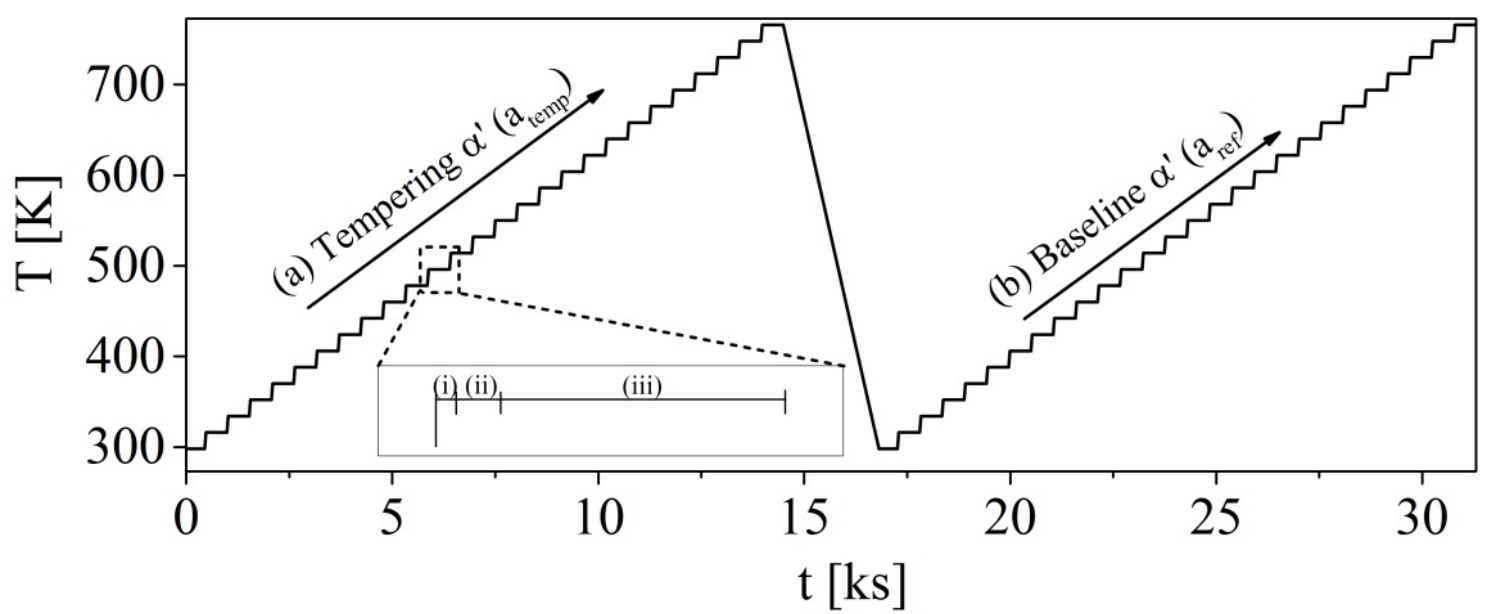

Figure 1 - Thermal cycles applied for measurement of the lattice parameter during (a) tempering of virgin martensite $\left(a_{\text {temp }}\right)$ and $(b)$ reheating of tempered martensite $\left(a_{\text {ref }}\right)$. The average heating and cooling with $0.033 \mathrm{~K}^{-1}{ }^{-1}$ was discretized into isothermal plateaus of $540 \mathrm{~s}$ consisting of (i) rapid heating $\left(0.6 \mathrm{~K}^{-1}\right.$ ), (ii) $80 \mathrm{~s}$ equilibration and (iii) $430 \mathrm{~s}$ of $\sin ^{2} \psi$-analysis at stationary thermal conditions (see inset). 


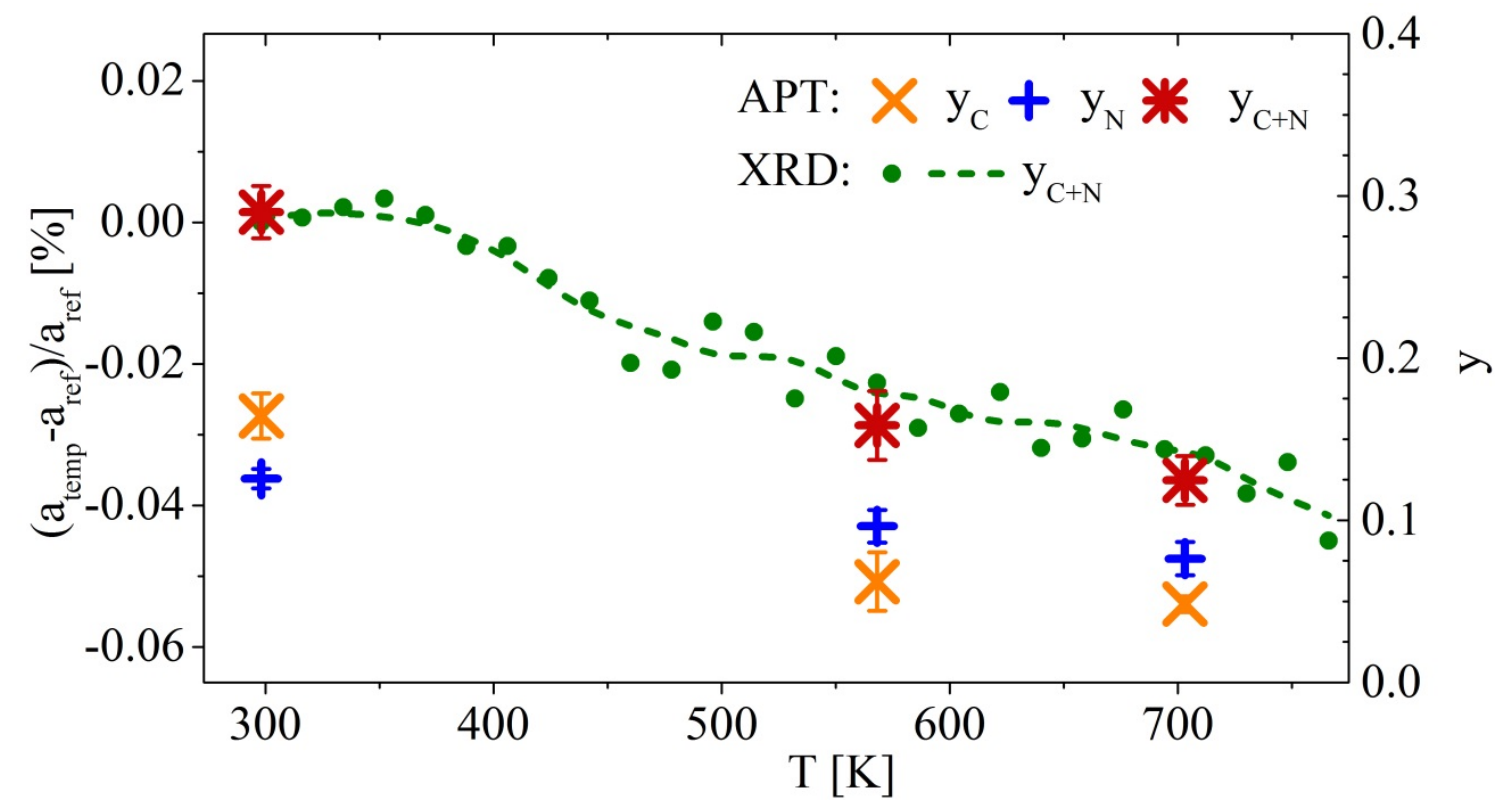

Figure 2 - The green data points and dashed curve show the relative change in the martensite lattice parameter as determined by XRD during tempering (left y-axis). The conversion of lattice expansion to the change in total interstitial content (equation 1) starting from the average $C$ and $N$ alloy content is given on the right $y$-axis. Data points show $C$ and $N$ concentrations from chemical analysis of the bulk by APT, excluding segregated areas at lattice defects. The error bars represent the standard deviation from measurements of different samples of the same tempering condition, weighted by their number of ions. Data originates from $>5 \times 10^{6}$ ions per sample and in total $9>\mathbf{5 0} \times \mathbf{1 0}^{6}$ ions per tempering condition. 
a)

b) 0.4 bulk

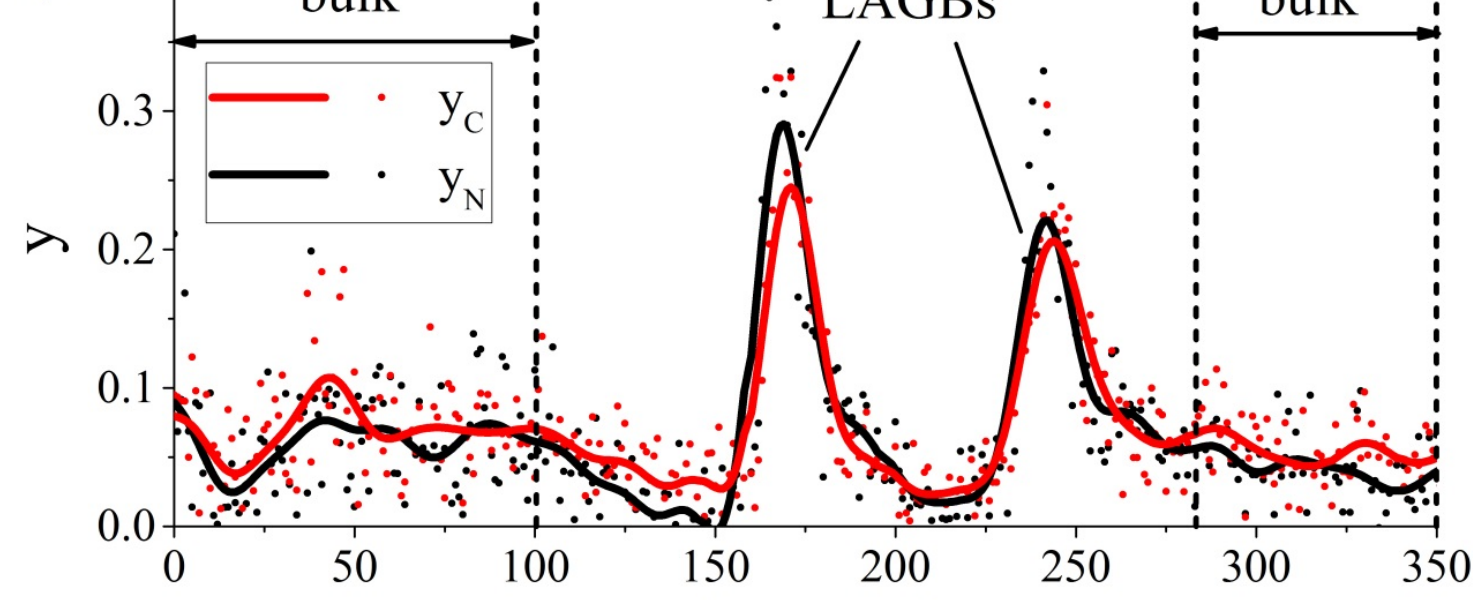

Distance [nm]

Figure 3 - Carbon and nitrogen content profiles along the longitudinal axis of an APT analysis of the $703 \mathrm{~K}$ tempered condition (b) and reconstruction of the $\mathrm{C}$-atom distribution (a). The bulk contents in Figure 2 were determined within the areas indicated "bulk", with distance from segregation features and corresponding depleted zones. 